\title{
Characterization of $\mathbf{E}$ coli phage isolated from sewage
}

\author{
G.A. Al-Mola \\ I. H. Al-Yassari \\ Coll. of Uloom Al-Banat / Unive of Babylon
}

\begin{abstract}
Bacteriophage are viruses that infect bacterial cells. as with all viruses, phage are nonliving agents and thus require the use of the host's metabolic processes to replicate itself. in this study, the phage of interest are those that infect and lyses E. colt host cells. when phage are released from the ruptured host, distinct zones of clearing (plaques) form. the original $E$. colt host cells for this experiment came from a sample of raw sewage. in order to obtain the bacteriophage, a procedure of enrichment, isolation, dilution and seeding was followed, the presence of distinct plaques indicated that lytic bacteriophage had been successfully amplified, separated and grown.This study included determination of phage titre, latent period , rise period and the burst size of the phage and effect some of factor on phage titre such as (temperature, ether and chloroform) .for determination ofhage titre used series of dilutions $\left(10^{-}\right.$ ${ }^{1}, 10^{-2}, 10^{-3}, 10^{-4}, 10^{-4}, 10^{-6}, 10^{-7}, 10^{-8}, 10^{-9}$ ) the dilution factor gave the best countable number of plaques is $\left(10^{3}\right)$. this dilution factor was then used for all other experiments, the latent period, rise period and the burst size of the phage are determined by countable number of plaques and phage titre(titer: plaque-forming unit(p.f.u) during 10,20,30,40,50, and 60 minutes . it was $\left(4.7 \times 10^{5} \cdot 5.3 \times 105\right.$ and $\left.6.0 \times 105\right)$ during 10,20 and30minutes respectively in the latent period ,but it was $\left(8.5 \times 1058.9 \times 10^{\prime}\right.$ 9.3×105)during 40,50, and 60 minutes respectively in the rise period .then the burst size of the phage is counted by the ratio of the phage titer after rise period to that during the latent period it was(1.67).This study also included effect of temperature on phage titre the statistical analysis was significantly increase $\mathrm{P}<0.05$ in phage titre at the temperature $37 \mathrm{C}^{\circ}$ comparing with phage titre at the temperature $50 \mathrm{C}^{\circ}$ and phage titre at the temperature $65 \mathrm{C}^{\circ}$. effects of ether and chloroform on number of plaques and phage titre during $5,10,15,20,25,30,35$ and 40 minutes it was $(0.7 \times 105,0.3 \times 105$ $, 0,0,0,0,0$ and 0 ) respectively in ether sensitivity, but the phage titre in chloroform sensitivity was completely inactivated by chloroform treatment, the statistical analysis (freedom degree $(2,21)$ and $\mathrm{F}$ value $=52.60$ was high] significant increase $(\mathrm{P}<0.05)$ in phage titre in normal saline comparing with phage titre in ether and chloroform sensitivity.
\end{abstract}

\section{Introduction}

Bacteriophage are viruses that infect bacteria (bacteriophage means bacteria eater).(2)(3) bacteriophage are small viruses that infect bacteria and kill them by multiplying and basically filling the bacterial cell to bursting. they don't affect the infected host, because bacteriophage activity ceases once the bacterial cells are killed. Bacteriophage, which exist in many varieties, do not attack bacteria indiscriminately, they each usually attack only one specific kind(3)(4). Most phages are 24-200 nm in length. head or capsid - every phage has a head structure, which can vary in size and shape. Some are icosahedral (20 sides), others are lilamentous. The head (or capsid) is composed of many copies of one or more type of protein, and it contains the phage's genetic material (i.e. nucleic acid). The genetic material can be ssRNA, dsRNA, ssDNA, or dsDNA between 5 and 500 kilo base pairs $(\mathrm{kbp})$ long in either a circular or linear arrangement(5)(6)(7).Tail - many, but not all, phages have tails attached to the phage head, the tail is a hollow tube through which the nucleic acid passes during infection, and its size can vary considerably. in the more complex phages, like $\mathrm{T} 4$, the tail is surrounded by a contractile sheath which contracts during infection of the bacterium, at the end of the tail, some phages have a base plate and one or more tail fibers attached to it; these structures are involved in the attachment of the phage to the bacterial cell (8) to enter a host cell, bacteriophages attach to specific receptors on the surface of bacteria, 
including lipopolysaccharides, teichoic acids, proteins or even flagella. this specificity means that a bacteriophage can only enter bacteria that bear the certain types of receptors that they can bind to, and it is these portals of entry that determine the phage's "host range" (9) (10). phages may be released via cell lysis or by host cell secretion. in $\mathrm{T} 4$ phage, upwards of three hundred phages will be released via lysis in approximately twenty minutes after injection, host lysis is usually achieved through an enzyme called endolysin which attacks and breaks down the cell wall structure surrounding the bacterial cell which is composed of a sugar- amino acid co-polymer called peptidoglycan (11).Bacteriophage that infect $E$. coil sometimes are referred to coliphage generally, bacteriophage are referred to simply as phage. As is true for all viruses, phage can replicate only within host cells. In other words, coliphage can replicate only within E.coli(12).Phage must attach to a receptor on the surface of a bacterial cell in order to initiate an infection. This interaction between the phage and receptor is very specific - a given phase type only will bind to a specific receptor molecule. thus, all phage are not alike(13).The study of bacteriophage lead to a number of observations that suggest reconsideration of phage therapy might provide a mechanism for circumventing the rising concerns about the growing spectrum of resistance to antibiotics by using a new approach(14(15).The aim of the present work was to characterization of $E$ coil phage isolated from sewage, determine the phage titre and study the effect of some factors as temperature, ether and chloroform.

\section{Materials and Methods}

The methods used were adapted from (16)Phage isolation Enrichment (amplification of phage).Measure out 45 $\mathrm{ml}$ raw sewage into graduated cylinder and decant into erlenmeyer flask and pipette 5 $\mathrm{ml}$ double sterile phosphate buffer saline and $5 \mathrm{ml} \mathrm{E}$. coil into the sewage flask then incubate flask at $37^{\circ} \mathrm{C}$ for 24 hours. Isolation of phage and seeding: distribution of sewage and E. coil mixture into 8 centrifuge tubes, filling each up to within $1 / 2$ inch from the top and then pipette the liquid into a membrane filter assembly and run vacuum until all the liquid is pulled into the container then transfer the final filtrate from the filtration assembly to a flask and liquefy four tubes (labeled 1-4) of $5 \mathrm{~mL}$ soft nutrient agar and maintain a $50^{\circ} \mathrm{C}$ temperature then pour tubes quickly onto corresponding hard nutrient agar plates (labeled 1 - 4) before soft nutrient agar hardens finally incubate plates at $37^{\circ} \mathrm{C}$ for 24 hours. (if possible, check plates at 6 hour intervals. Determination Phage titer : made dilutions of $\left(10^{-1}, 10^{-2}, 10^{-3}, 10^{-4}, 10^{-4}, 10^{-6}, 10^{-7}, 10^{-}\right.$ $\left.8,10^{-9}\right)$ of the sample and then plated $0.1 \mathrm{ml}$ each of the dilution and the E.coli culture onto NA plates and then incubated overnight, after which the phage titre could be determined by counting the number of plaque forming units (p.f.u.) for each dilution. For determination (dilution factor) to used for all other experiments:Counting the number of plaque forming units (p.f.u.) for each dilution it was also determined at this stage which dilution factor gave the best countable number of plaques. this dilution factor was then used for all other experiments.Determination of Latent period, Rise period and the Burst size of the phage the tube was mixed and placed in a $37 \mathrm{C}$ water bath. $0.1 \mathrm{ml}$ of this culture was removed after 10,20,30,40,50, and 60 minutes had elapsed. Just before the culture was removed at each time interval, $0.1 \mathrm{ml}$ of E.coll culture was added to a sloppy agar tube to which the culture from the water bath was added. this was then plated immediately on NA plates and incubated overnight, the number of p.f.u. was then determined for each time A latent period, characterized by a steady low level of viruses a rise period, characterized by a sudden increase in the number of viruses the burst size of the virus or the number of viruses released by an individual bacterium 
is given by the ratio of the phage titer after the burst to that during the latent period.

determination Temperature sensitivity:

Optimal phage dilution were prepared using saline and one placed in a $50 \mathrm{C}$, the other in a $65 \mathrm{C}$ water bath and $37 \mathrm{C}$ as a control . $0.1 \mathrm{ml}$ of phage dilution were removed after 10,20,30,40,50, and $60 \mathrm{~mm}$ had elapsed and added to sloppy agar previously inoculated with E.coli culture then plated on NA and incubated overnight at each temperature the number of p.f.u. were determined for each time interval and this was plotted versus time exposed to that temperature. determination Ether! chloroform sensitivity:

$0.1 \mathrm{ml}$ of the optimal phage dilution, diluted using saline, was added to $0.9 \mathrm{ml}$ ether. after 5,10,15,20,25,30,35, and 40mm had elapsed $0.1 \mathrm{ml}$ was removed from this tube and added to sloppy agar, which had been previously inoculated with E.coli

\section{Results and discussion}

In this study, the phage of interest are those that infect and lyses $E$. colt host cells. when phage are released from the ruptured host, distinct zones of clearing (plaques) form, the original E. colt host cells for this experiments came from a sample of raw sewage. in order to obtain the bacteriophage, a procedure of enrichment, isolation, dilution and seeding was followed, the presence of distinct plaques indicated that lytic bacteriophage had been successfully amplified, separated and grown. this study included determination of phage titre by using series of dilutions $\left(10^{-1}, 10^{-2}, 10^{-3}, 10^{-4}, 10^{-4}, 10^{-6}\right.$, $10^{-7}, 10^{-8}, 10^{-9}$ ) and counting the number of plaque forming units (p.f.u.) for each dilution it was $\left(770 \times 10^{-1}, 860 \times 10^{-2}\right.$, $900 \times 10^{-3}, 650 \times 10^{-4}, 470 \times 10^{-5} 230 \times 10^{-6}$, $20 \times 10^{-7}, 0$ and 0 respectively)this results means that the dilution factor gave the best countable number of plaques is $\left(10^{-3}\right)$. this culture. This was then plated on NA and incubated overnight. $0.1 \mathrm{ml}$ of phage dilution was added to $0.9 \mathrm{ml}$ of chloroform and mixed after 5,10,15,20,25,30,35, and $40 \mathrm{~mm}$ had elapsed $0.1 \mathrm{ml}$ was removed from this tube and added to sloppy agar, which had been previously inoculated with E.coli culture. this was then plated on NA and incubated overnight, the number of p.f.u. were determined for each time.

\section{Statistical analysis:}

Statistical analysis were conducted to describe different variables and parameters in the research, and to describe relationship with each other as well, calculation of mean value and standard deviation (SD) were made for immunological parameters. the statistical significance of difference in mean of variable between more than two groups was assessed by ANOVA test .probability values of $\mathrm{P}<0.05$ were considered statistically significant. dilution factor was then used for all other experiments Table (1). the presence of these zones of clearing indicated that the first part of the hypothesis was proven, that is, amplifying bacteriophage from a raw sewage sample and inoculating the phage into $F$. colt host was an effective way of isolating (and visualizing) phage (17).Amplify (increase the numbers) of phages in the sewage sample by allowing them to infect and reproduce within fresh E. co/i, The infection then "spread" as the viruses reproduced and cells lysed, eventually forming a visible plaque the titer of a phage suspension, therefore, is determined by counting the number of plaques that form from a given volume of suspension. phage titer is expressed as plaque forming units (PFU) per milliliter (ml). it was also determined at this stage which dilution factor gave the best countable number of plaques(18) 
Table(1):determination of phage titer

\begin{tabular}{|c|c|c|c|c|c|c|}
\hline $\begin{array}{c}\text { Plate } \\
\text { NO. }\end{array}$ & $\begin{array}{c}\text { Volume of } \\
\text { phage } \\
\text { plated (ml } \\
)\end{array}$ & Dilution & $\begin{array}{c}\text { Dilution } \\
\text { Factor (DF) }\end{array}$ & $\begin{array}{c}\text { Plaque } \\
\text { per } \\
\text { plate }\end{array}$ & $\begin{array}{c}\text { Titer calculation }= \\
\text { Plaquex DF / } \\
\text { Volume of phage } \\
\text { plated (ml ) }\end{array}$ & $\begin{array}{c}\text { Titer } \\
\text { Plaque } \\
\text { forming } \\
\text { unit }\end{array}$ \\
\hline 1 & 0.1 & $10^{-1}$ & $10^{1}$ & 77 & $77 \times 10^{1} / 0.1$ & $770 \times 10^{1}$ \\
\hline 2 & 0.1 & $10^{-1}$ & $10^{2}$ & 86 & $86 \times 10^{2} / 0.1$ & $860 \times 10^{2}$ \\
\hline 3 & 0.1 & $10^{-1}$ & $10^{3}$ & 90 & $90 \times 10^{3} / 0.1$ & $900 \times 10^{3}$ \\
\hline 4 & 0.1 & $10^{-1}$ & $10^{4}$ & 65 & $65 \times 10^{4} / 0.1$ & $650 \times 10^{4}$ \\
\hline 5 & 0.1 & $10^{-1}$ & $10^{5}$ & 47 & $47 \times 10^{5} / 0.1$ & $470 \times 10^{5}$ \\
\hline 6 & 0.1 & $10^{-1}$ & $10^{6}$ & 23 & $23 \times 10^{6} / 0.1$ & $230 \times 10^{6}$ \\
\hline 7 & 0.1 & $10^{-1}$ & $10^{7}$ & 2 & $2 \times 10^{7} / 0.1$ & $2 \times 10^{7}$ \\
\hline 8 & 0.1 & $10^{-1}$ & $10^{8}$ & 0 & $0 \times 10^{8} / 0.1$ & $0 \times 10^{8}$ \\
\hline 9 & 0.1 & $10^{-1}$ & $10^{9}$ & 0 & $0 \times 10^{9} / 0.1$ & $0 \times 10^{9}$ \\
\hline
\end{tabular}

The latent period, rise period and the burst size of the phage are determined by countable number of plaques and phage titre(titer: plaque-forming unit (p.f.u)) during $10,20,30,40,50$, and 60 minutes. it was $\left(4.7 \times 10^{-5} 5.3 \times 10^{-5}\right.$ and $\left.6.0 \times 10^{-5}\right)$ during 10,2 Oand30minutes respectively in the latent period ,but it was $\left(8.5 \times 10^{-5} 8.9 \times 10^{-5}\right.$ $9.3 \times 105$ ) during 40,50, and 6ominutes respectively in the rise period then the burst size of the phage is counted by the ratio of the phage titer after rise period to that during the latent period it was(1.67) Table (2).the statistical analysis in freedom degree $(1,4)$ and $F$ value $=65.423$ was significant different $(\mathrm{P}<0.05)$ in comparing between rise period and latent period. Another study done by (Jarvis, A.,1989) (19) on latent period, characterized by a steady low level of viruses 870 p.f.u/ml, was followed by a sudden increase in the number of viruses or a rise period, to a titre of 2500 p.f.u./ml.(Soloff, B. eLaI.,1978) (20). found the burst size of the virus or the number of viruses released by an individual bacterium is given by the ratio of the phage titre after the burst to that during the latent period. In this case it turned out to be 3 phages released per infected bacterium. Important characteristics of the viral reproductive process such as the number of bacteria. Released per infected cell and the time it takes to produce new viruses can readily be determined by plotting a single step growth curve. These important characteristics vary between viruses but are often similar for related ones. Thus, they can serve as taxonomic criteria, mostly for high-level taxonomy. The number of released phages or burst size, and the time it takes to make them or latent period, are mainly determined by the complexity and size of the virion so it is expected that these criteria are conserved between phages with similar morphology(21). This study also included effect some of characterization on phage titre such as (temperature, ether and chloroform) our results about temperature sensitivity effect on number of plaques and phage titre during $10,20,30,40,50$, and 60 minutes was $\left(4.7 \times 10^{-5}, 5.3 \times 10^{-5}, 6.0 \times 10^{-5}\right.$ $8.5 \times 10^{-5} 8.9 \times 10^{-5}$ and $9.3 \times 10^{-5}$ ) respectively in the temperature $37 \mathrm{C}^{\circ}$. and phage titre was $\left(6.2 \times 10^{-5}, 5.6 \times 10^{-5}, 4.1\right.$ $\times 10^{-5} 3.6 \times 10^{-5}, 2.0 \times 10^{-5}$ and $1.6 \times 10^{-}$ ${ }^{5}$ respectively in the temperature $5 \mathrm{o} \mathrm{C}^{\circ}$. The phage titre was $\left(0.9 \times 10^{-5} 0.1 \times 10^{-5}, 0,0,0\right.$ and 0 ) respectively in the temperature 65 $\mathrm{C}^{\circ}$ Table (3). The statistical analysis in freedom degree $(2,15)$ and $F$ value $=28.562 \mathrm{was}$ significant increase $(\mathrm{P}<0.05)$ in phage titre in temperature $37 \mathrm{C}^{\circ}$ comparing with phage titre in temperature50 $\mathrm{C}^{\circ}$ and phage titre in temperature $65 \mathrm{C}^{\circ}$. most are susceptible to temperatures above $60^{\circ} \mathrm{C}$ and inactivated immediately at $100^{\circ} \mathrm{C}(22)$. The temperature at which a phage looses viability is called thermal inactivation temperature. This loss of viability has been shown to result from 
disruption of head proteins and the subsequent release of DNA, and the alteration of phage binding receptors (adsorption sites) (23).

Table(2):determination of Latent period, Rise period and the Burst size of the phage( the number of phage released by an individual bacterium).

\begin{tabular}{|c|c|c|c|c|c|c|c|c|c|}
\hline $\begin{array}{l}\text { Time } \\
(\mathrm{min})\end{array}$ & $\begin{array}{c}\text { Volume } \\
\text { of phage } \\
\text { plated } \\
(\mathrm{ml})\end{array}$ & $\begin{array}{l}\text { Dilution } \\
\text { Factor } \\
\text { (DF) }\end{array}$ & $\begin{array}{l}\text { Plaque } \\
\text { per } \\
\text { plate }\end{array}$ & $\begin{array}{c}\text { Titer } \\
\text { Plaque } \\
\text { forming } \\
\text { unit }\end{array}$ & $\begin{array}{l}\text { Type } \\
\text { of } \\
\text { period }\end{array}$ & Means & $\begin{array}{c}\text { Std. } \\
\text { Deviation }\end{array}$ & $\begin{array}{l}\text { Std. } \\
\text { Error }\end{array}$ & Burst size \\
\hline 10 & 0.1 & $10^{3}$ & 47 & $4.7 \times 10^{5}$ & \multirow{3}{*}{$\begin{array}{l}\text { Latent } \\
\text { period }\end{array}$} & \multirow{3}{*}{5.3333} & \multirow{3}{*}{0.6506} & \multirow{3}{*}{0.3756} & \multirow{6}{*}{$\begin{array}{l}\text { Phage Titer } \\
\text { after Rise } \\
\text { period } / \text { Phage } \\
\text { Titer during } \\
\text { Latent period= } \\
1.67\end{array}$} \\
\hline 20 & 0.1 & $10^{3}$ & 53 & $5.3 \times 10^{5}$ & & & & & \\
\hline 30 & 0.1 & $10^{3}$ & 60 & $6.0 \times 10^{5}$ & & & & & \\
\hline 40 & 0.1 & $10^{3}$ & 85 & $8.5 \times 10^{5}$ & \multirow{3}{*}{$\begin{array}{l}\text { Rise } \\
\text { period }\end{array}$} & \multirow{3}{*}{8.9000} & \multirow{3}{*}{0.4000} & \multirow{3}{*}{0.2309} & \\
\hline 50 & 0.1 & $10^{3}$ & 89 & $8.9 \times 10^{5}$ & & & & & \\
\hline 60 & 0.1 & $10^{3}$ & 93 & $9.3 \times 10^{5}$ & & & & & \\
\hline
\end{tabular}

Table(3):determination sensitivity of phage titer in relation to temperature $\left(37 \mathrm{C}^{\circ}, \mathrm{SOC}^{\circ}\right.$ and $\left.65 \mathrm{C}^{\circ}\right)$.

\begin{tabular}{|c|c|c|c|c|c|}
\hline \multirow[b]{2}{*}{$\begin{array}{l}\text { Time } \\
(\min )\end{array}$} & \multirow{2}{*}{$\begin{array}{l}\text { Volume of } \\
\text { phage plated } \\
(\mathrm{ml})\end{array}$} & \multirow[b]{2}{*}{$\begin{array}{c}\text { Dilution } \\
\text { Factor ( DF) }\end{array}$} & \multicolumn{3}{|c|}{ Titer: Plaque forming unit } \\
\hline & & & $\begin{array}{c}37 \mathrm{C}^{\circ} \text { (as } \\
\text { control group) }\end{array}$ & $50 \mathrm{C}^{\circ}$ & $65 \mathrm{C}^{\circ}$ \\
\hline 10 & 0.1 & $10^{3}$ & $4.7 \times 10^{-5}$ & $6.2 \times 10^{-5}$ & $4.7 \times 10^{-5}$ \\
\hline 20 & 0.1 & $10^{3}$ & $5.3 \times 10^{-5}$ & $5.6 \times 10^{-5}$ & $4.7 \times 10^{-5}$ \\
\hline 30 & 0.1 & $10^{3}$ & $6.0 \times 10^{-5}$ & $4.1 \times 10^{-5}$ & 0 \\
\hline 40 & 0.1 & $10^{3}$ & $8.5 \times 10^{-5}$ & $3.6 \times 10^{-5}$ & 0 \\
\hline 50 & 0.1 & $10^{3}$ & $8.9 \times 10^{-5}$ & $2.0 \times 10^{-5}$ & 0 \\
\hline 60 & 0.1 & $10^{3}$ & $9.3 \times 10^{-5}$ & $1.6 \times 10^{-5}$ & 0 \\
\hline \multicolumn{3}{|c|}{ Means } & $7.1167 \times 10^{-5}$ & $3.8500 \times 10^{-5}$ & $0.1667 \times 10^{-5}$ \\
\hline \multicolumn{3}{|c|}{ Std. Deviation } & $2.0124 \times 10^{-5}$ & $1.8545 \times 10^{-5}$ & $0.3615 \times 10^{-5}$ \\
\hline \multicolumn{3}{|c|}{ Std. Error } & $0.8216 \times 10^{-5}$ & $0.7571 \times 10^{-5}$ & $0.1476 \times 10^{-5}$ \\
\hline \multicolumn{3}{|c|}{ Minimum } & $4.70 \times 10^{-5}$ & $1.60 \times 10^{-5}$ & 0.00 \\
\hline \multicolumn{3}{|c|}{ Maximum } & $9.30 \times 10^{-5}$ & $6.20 \times 10^{-5}$ & $0.90 \times 10^{-5}$ \\
\hline
\end{tabular}

Table (4) showed effect ether and chloroform on number of plaques and phage titre during $5,10,15,20,25,30,35$ and 40 minutes it was $\left(0.7 \times 10^{-5}, 0.3 \times 10^{-5}\right.$, $0^{\prime} 0^{\prime} 0^{\prime} 0$ ' 0 and 0 ) respectively in ether sensitivity, but the phage titre was ( 0 ' 0 ' 0 ' 0 ' 0 ' $\quad 0$ ' 0 and 0 ) respectively in chloroform sensitivity that means the phage was completely - inactivated by chloroform treatment, and the phage titre was $\left(2.0 \times 10^{-5} 3.2 \times 10^{-5} 4.7 \times 10^{-5}\right.$ ، $5.1 \times 10^{-}$ 5 ، $5.8 \times 10^{-5}$ ' $6.6 \times 10^{-5}, 7.4 \times 10^{-5}$, and 8.0 $\mathrm{x} 10^{-5}$ ) respectively in normal saline as a control group. The statical analysis in freedom degree ( 2,21 ) and $F$ value $=52.60$ was high significant different $\mathrm{P}<0.05$ in phage titre in normal saline comparing with phage titre in ether sensitivity and phage titre in chloroform sensitivity. (Bertani, L. and Bertani, G. 1986) (24). found some phage contain lipids as a structure components of their virions and so detection of any lipids in a virus restricts its possible identity to only a few families . (Sands, J. and Lowlicht,R. 1976) (25) showed these lipid are essential for maintaining the virus ability to infect new host. Any disruption of the lipid components will lead to a loss of viability of the virus, lipids are soluble in nonpolar solvents such as ether and chloroform, which are capable of extracting and disrupting the lipid components of the phages by interfering with the hydrophobic interactions between lipid molecules. Nonpolar solvents are capable of denaturing 
proteins by disrupting the hydrophobic also lead to a loss of viability(26).

interaction between proteins, which can

Table (4): determination of ether, chloroform and saline sensitivity of phage titers.

\begin{tabular}{|c|c|c|c|c|c|}
\hline \multirow[b]{2}{*}{$\begin{array}{l}\text { Time } \\
(\min )\end{array}$} & \multirow{2}{*}{$\begin{array}{l}\text { Volume of } \\
\text { phage plated } \\
(\mathrm{ml})\end{array}$} & \multirow[b]{2}{*}{$\begin{array}{c}\text { Dilution } \\
\text { Factor ( DF) }\end{array}$} & \multicolumn{3}{|c|}{ Titer: Plaque forming unit } \\
\hline & & & Ether & Chloroform & $\begin{array}{c}\text { Saline (as } \\
\text { control group) }\end{array}$ \\
\hline 5 & 0.1 & $10^{3}$ & $0.7 \times 10^{-5}$ & 0 & $2.0 \times 10^{-5}$ \\
\hline 10 & 0.1 & $10^{3}$ & $0.3 \times 10^{-5}$ & 0 & $3.2 \times 10^{-5}$ \\
\hline 15 & 0.1 & $10^{3}$ & 0 & 0 & $4.7 \times 10^{-5}$ \\
\hline 20 & 0.1 & $10^{3}$ & 0 & 0 & $5.1 \times 10^{-5}$ \\
\hline 25 & 0.1 & $10^{3}$ & 0 & 0 & $5.8 \times 10^{-5}$ \\
\hline 30 & 0.1 & $10^{3}$ & 0 & 0 & $6.6 \times 10^{-5}$ \\
\hline 35 & 0.1 & $10^{3}$ & 0 & 0 & $7.4 \times 10^{-5}$ \\
\hline 40 & 0.1 & $10^{3}$ & 0 & 0 & $8.0 \times 10^{-5}$ \\
\hline \multicolumn{3}{|c|}{ Means } & $0.1250 \times 10^{-5}$ & 0 & $5.3500 \times 10^{-5}$ \\
\hline \multicolumn{3}{|c|}{ Std. Deviation } & $0.2550 \times 10^{-5}$ & 0 & $2.0466 \times 10^{-5}$ \\
\hline \multicolumn{3}{|c|}{ Std. Error } & $0.014 \times 10^{-5}$ & 0 & $0.7236 \times 10^{-5}$ \\
\hline \multicolumn{3}{|c|}{ Minimum } & 0 & 0 & $2.00 \times 10^{-5}$ \\
\hline \multicolumn{3}{|c|}{ Maximum } & $0.7 \times 10^{-5}$ & 0 & $8.00 \times 10^{-5}$ \\
\hline
\end{tabular}

\section{References}

1. Edberg, S.C., Allen, M.J., Smith, D.B., Kriz, N.J., (1990). Enumeration of total coliforms and Escherichia coIl from source water by the defined substrate technology. Appi. Environ. Microbiol.56, 366-369.

2. Alisky, J., K. Iczkowski, A. Rapoport, and N. Troitsky. (1998). Bacteriophage show promise as antimicrobial agents. J Infect 36:515.

3. Krukowska, A., and S. Slopek. (1987). Immunogenic effect of bacteriophage in patients subjected to phage therapy. Arch. Immunol. Ther. Exp. 5:553-561.

4. Perepanova, T. 5., 0. S. Darbeeva, G. A. Kotliarova, E. M. Kondrat'eva,L. M. Maiskala, V. F. Malysheva, F. A. Baiguzina, and N. V. Grishkova.(1995). The efficacy of bacteriophage preparations in treating inflammatory urologic diseases. Urol. Nefrol. 5:14-17.

5. Eiserling, F. A. Bacteriophage structure, in Comprehensive Virology. (1979). Vol.13: 543, Fraenkel-Conrat, H. and Wagner,
R. R., Eds., Plenum Press, New York.

6. Hershey AD, and Chase M (1952). Independent functions of viral protein and nucleic acid in growth of bacteriophage. J Gen Physiol 36:39-56.

7. Ptashne M (1967). Isolation of lambda phage repressor. Proc NatI Acad Sci USA. 57:306-13

8. Ginoza, W. The effects of ionizing radiation on nucleic acids of bacteriophages and bacterial cell. (1967). Annu. Rev. Microbiol. 21, 325.

9. Rizvi, S., and P. D. Mora. (1963). Bacteriophage plaque-count assay and confluent lysis on plates without bottom agar layer. Nature (London) 200:1324.

10. Young, R., and U. Blasi. (1995). functions in bacteriophage lysis. FEMS Microbiol. Rev. 17:191-205.

11. Summers, W.C., (2001). Bacteriophage therapy. Ann. Rev. Microbiol. 55,437-451.

12. Havelaar, A. H., and W. H. Hogeboom. (1983). Factors affecting the 
enumeration of coliphages in sewage and sewage-polluted waters. Antonie Leeuwenhoek 49:387-397.

13. Bell, R. G. (1976). The limitation of the ratio of fecal coliforms to total coliphages as a faecal pollution index. Water Res. 10:743-748.

14. Cislo, M., M. Dabrowski, B. WeberDabrowska, and A. Woyton. (1987). Bacteriophage treatment of suppurative skin infections. Arch. Immunol. Ther. Exp. 2:175-183.

15. Grabow, W. 0. K., Very, A., Uys, M., de Villiers, J. C. (1998). Evaluation of the Application of Pathogens as indicators of Water Quality, Report to the Water Research Commission by the Department of Medical Virology, Faculty of Medicine, University of Pretoria, WRC Report No. 540/1/98:1-7.

16. Jaime M. and Tiffany F. (2003). Isolation of $\mathrm{E}$ coli Bacteriophage. Phage method 2,266-276.

17. Steele, P. R. M. Morphological manifestations of freezing and thawing injury in bacteriophage T4Bo. (1971). J. Hyg. 77, 119.

18. Yoon, S.-S., Kim, J.W., Breidt, F., Fleming, H.P., (2001). Characterization of a lytic Lactobacillus plantarum bacteriophage and molecular cloning of a lysin gene in Escherichia coli. mt. J. Food Microbiol. 65, 63-74.

19. Jarvis, A.W., (1989). Bacteriophage of Escherichia coli bacteria. S. Dairy Sci. 72,3406- 3428.
20. Soloff, B. L., Rado, T. A., Henry, B. E., and Bates, J. H. Biochemical and morphological characteristics of mycobacteriophage Ri. (1978). J. Virol. 25, 253.

21. Kaiser, G. (2000). Temperance of Phages. California State University Northridge. Molecular Microbiology 30: 295-304.

22. Bohannan, B..J.M., Lenski, R.E., (1997). The effect of resource enrichment on a ehemostat community of bacteria and phage. Ecology 78,2303-2315.

23. Slopek, S., B. Weber-Dabrowska, M. Dabrowski, and A. KucharewiczKrukowska. (1987). Results of bacteriophage treatment of suppurative bacterial infections in the years 1981-1986. Arch Immunol Ther Exp (Warsz) 35:569-83.

24. Bertani, L. E. and Bertani, G. Preparation and characterization of temperate non-inducible bacteriophage P2. (1986). J. Gen. Virol. 2, 357.

25. Sands, J.A. and Lowlieht, R.A. Temporal origin of viral phospholipids of enveloped bacteriophage qi. (1976). Can. S. Microbiol. 22, 154

26. Camerini- Otera, R. D. and Franklin, R. M. Structure and synthesis of a lipid- containing bacteriophage. XII. The fatty acids and lipid content of bacteriophage PM2. (1972). Virology. 49, 385. 


\title{
دراسة عاثي بكتريا الايشيريشيا كولاي المعزولة من المياه الثقيلة
}

\author{
غانم المولى عماد هادي اليساري \\ كلية علوم البنات/جامعة بابل اليل \\ الخلاصة النات الجعة
}

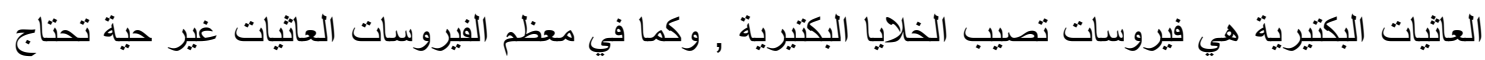

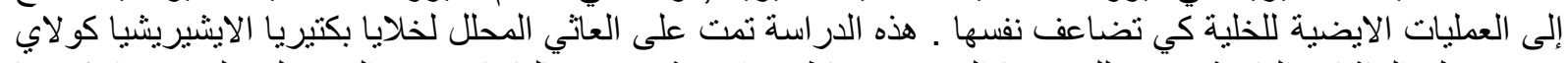

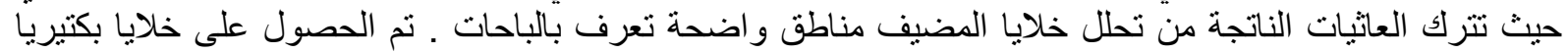

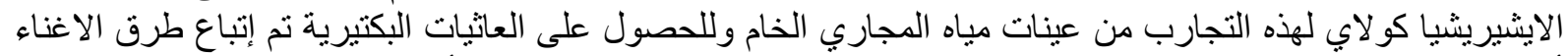

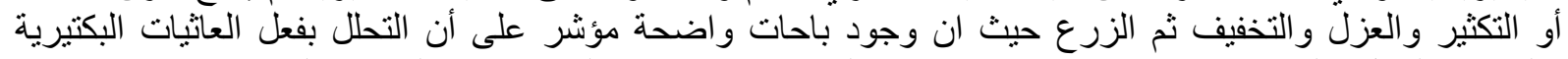

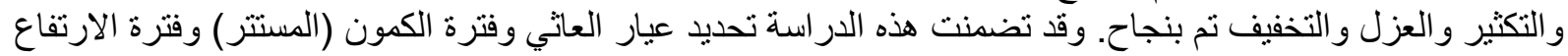

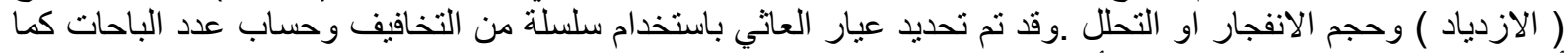

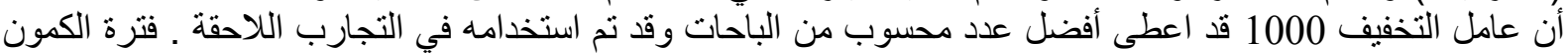

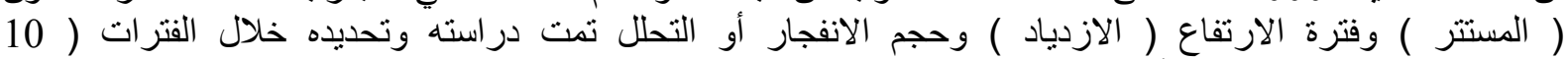

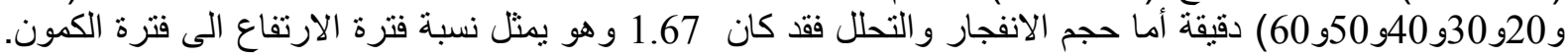

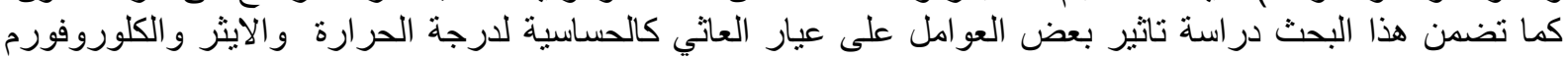

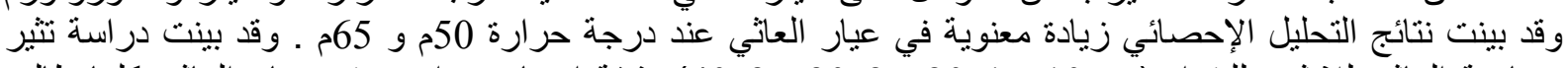

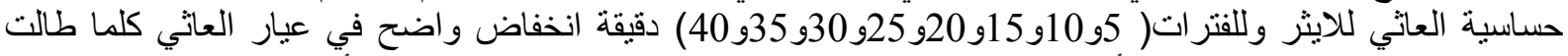

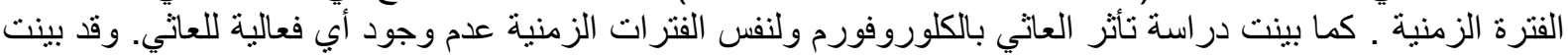

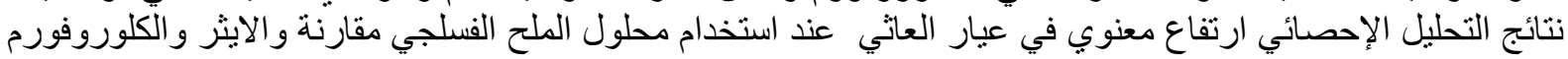

